\title{
AUTOMATION, ROBOTICS
}

T 125

AUTOMATIZAVIMAS, ROBOTECHNIKA

\section{Design of the Deadbeat Controller with Limited Output}

\section{Balasevicius, G. Dervinis}

Department of Control Technology, Kaunas University of Technology,

Studentu str.48-324, LT-51367 Kaunas, Lithuania, phone: +370 37 300294, e-mail: valtek@ktu.lt

\section{Introduction}

Deadbeat control system is digital control system. The deadbeat control could be used in systems where the known finite settling time is required. In this article, the presented deadbeat controller design is based on the object $z$-transfer function. The overall structure of the control system is shown in Fig. 1.

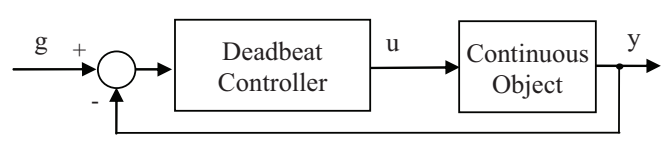

Fig. 1. Structure of the control system: $g$ - reference input; $u-$ manipulated variable (controller output); $y$ - system output

It is known that the deadbeat controller transfer function $W_{D C}(z)$ may be written as the following [1]

$$
\mathrm{W}_{\mathrm{DC}}(\mathrm{z})=\frac{\mathrm{Q}(\mathrm{z})}{1-\mathrm{P}(\mathrm{z})},
$$

where $Q(z), P(z)$ are the polynomials of the transfer function of the deadbeat controller. The coefficients of the polynomials $Q(z), P(z)$ are found by using these equations:

$$
\left\{\begin{array}{l}
\mathrm{q}_{0}=\frac{1}{\mathrm{~b}_{1}+\mathrm{b}_{2}+\ldots+\mathrm{b}_{\mathrm{m}}} \\
\mathrm{q}_{\mathrm{i}}=\mathrm{q}_{0} \cdot \mathrm{a}_{\mathrm{i}}, \\
\mathrm{p}_{\mathrm{i}}=\mathrm{q}_{0} \cdot \mathrm{b}_{\mathrm{i}}, \quad \mathrm{i}=1, \ldots, \mathrm{m}
\end{array}\right.
$$

where $a_{i}, b_{i}$ are coefficients of the polynomials of the continuous object's $z$-transfer function $\mathrm{W}_{\mathrm{CO}}(\mathrm{z})=\frac{\mathrm{B}(\mathrm{z})}{\mathrm{A}(\mathrm{z})} ; m$ - order of the object transfer function. The coefficients of polynomial $Q(z)$ can be expressed as [1]:

$$
\left\{\begin{array}{l}
\mathrm{q}_{0}=\mathrm{u}(0), \\
\mathrm{q}_{\mathrm{i}}=\mathrm{u}(\mathrm{i})-\mathrm{u}(\mathrm{i}-1), \quad \mathrm{i}=1, \ldots, \mathrm{m} .
\end{array}\right.
$$

Thus the initial value of manipulated variable $u(0)$ depends only on the sum (2) of the object's $z$-transfer function coefficients $b_{i}$.

The main drawback of the deadbeat controller is that the sampling time $T_{0}$ and manipulated variable $u(0)$ are inversely proportional. $T_{0}$ is conditioned by $u_{\max }$, which depends from various factors.

\section{Deadbeat controller with limited output}

By multiplying the numerator and the denominator polynomials of the controller's transfer function (1) by an additional polynomial $\mathrm{C}(\mathrm{z})[1]$ we get

$$
\mathrm{W}_{\mathrm{DC}}(\mathrm{z})=\frac{\mathrm{Q}(\mathrm{z}) \mathrm{C}(\mathrm{z})}{1-\mathrm{P}(\mathrm{z}) \mathrm{C}(\mathrm{z})}
$$

where $C(z)=1+c_{1} z^{-1}$. The coefficients of the deadbeat controller are found using these equations:

$$
\left\{\begin{array}{l}
\mathrm{q}_{0}=\frac{1}{\left(\mathrm{~b}_{1}+\mathrm{b}_{2}+\ldots+\mathrm{b}_{\mathrm{m}}\right)\left(1+c_{1}\right)}, \\
\mathrm{q}_{\mathrm{i}}=\mathrm{q}_{0} \cdot\left(\mathrm{a}_{\mathrm{i}}+\mathrm{a}_{\mathrm{i}-1} \cdot \mathrm{c}_{1}\right), \\
\mathrm{p}_{\mathrm{i}}=\mathrm{q}_{0} \cdot\left(\mathrm{b}_{\mathrm{i}}+\mathrm{b}_{\mathrm{i}-1} \cdot c_{1}\right), \quad \mathrm{i}=1, \ldots, \mathrm{m} .
\end{array}\right.
$$

The deadbeat controller's properties depend from coefficient $c_{1}$. If we assume that $u(0) \leq u_{\max }$, then using equations (3) and (5), the following can be written

$$
c_{10}=c_{1}=\frac{1}{U_{\max } \cdot\left(\mathrm{b}_{1}+\mathrm{b}_{2}+\ldots+\mathrm{b}_{\mathrm{m}}\right)}-1,
$$

where $c_{10}-$ a coefficient limiting the value of the manipulated variable from the top at time moment zero. So, if $c_{1} \geq c_{10}$ then $u(0) \leq u_{\max }$.

Let us assume that $-u(0) \leq u(1) \leq u(0)$, then express $u(0)$ and $u(1)$ in terms of $q_{i}$ by using (3) and (5)

$$
-q_{0} \leq q_{0}+q_{0} a_{1}+q_{0} c_{1} \leq q_{0} .
$$

Dividing inequality (7) from $q_{0}\left(q_{0}>0\right)$ we get

$$
-2 \leq a_{1}+c_{1} \leq 0
$$

Significant (8) boundary is expression 


$$
c_{11}=c_{1}=-a_{1},
$$

where $c_{11}-$ a coefficient limiting the value of the manipulated variable at time moment one. So, if $c_{1} \leq c_{11}$ then $|u(1)| \leq u_{\max }$.

Let us assume that $-u(0) \leq u(2) \leq u(0)$, then express $u(0)$ and $u(2)$ in terms of $q_{i}$ by using (3) and (5)

$$
-q_{0} \leq q_{0}+q_{0} a_{1}+q_{0} c_{1}+q_{0} a_{2}+q_{0} a_{1} c_{1} \leq q_{0} .
$$

Dividing the inequality (10) by $q_{0}\left(q_{0}>0\right)$ and rearranging we get

$$
-2-a_{1}-a_{2} \leq c_{1}\left(1+a_{1}\right) \leq-a_{1}-a_{2} .
$$

The expression $\left(1+a_{1}\right)$ in inequality (11) may be either positive or negative. If it is positive, then

$$
\frac{-2-a_{1}-a_{2}}{1+a_{1}} \leq c_{1} \leq \frac{-a_{1}-a_{2}}{1+a_{1}} \Rightarrow c_{121} .
$$

If $\left(1+a_{1}\right)$ is negative, then

$$
\frac{-2-a_{1}-a_{2}}{1+a_{1}} \geq c_{1} \geq \frac{-a_{1}-a_{2}}{1+a_{1}} \Rightarrow c_{122} .
$$

If $\left|a_{1}\right|>\left|a_{2}\right|$ in equation (11), then:

$$
\begin{aligned}
& c_{121}=\frac{-2-a_{1}-a_{2}}{1+a_{1}}, \\
& c_{122}=\frac{-a_{1}-a_{2}}{1+a_{1}},
\end{aligned}
$$

where $c_{121}, c_{122}$ - coefficients limiting the value of the manipulated variable at time moment two.

Such procedures are included in the design of deadbeat controller with limited manipulated variable.

Using equations (6), (9), (14) and (15) it is necessary to find the values of coefficients $c_{10}, c_{11}, c_{121}, c_{122}$ at different sampling time $T_{0}$ values and to draw dependencies $\quad c_{10}=f\left(T_{0}\right), \quad c_{11}=f\left(T_{0}\right), \quad c_{121}=f\left(T_{0}\right), \quad c_{122}=f\left(T_{0}\right)$ (see Fig.2.).

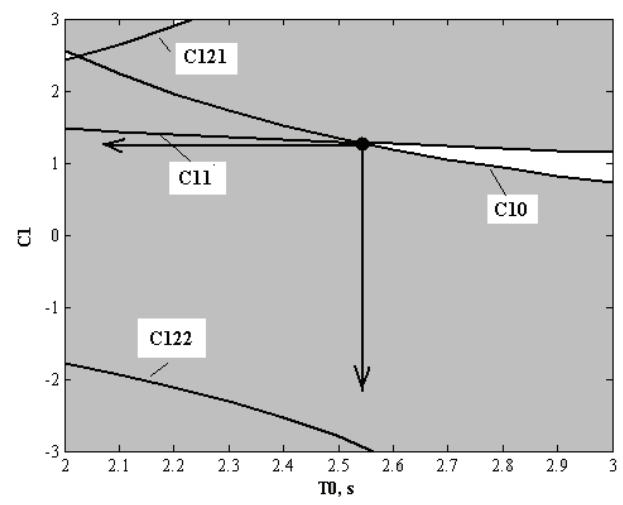

Fig. 2. Deadbeat controller with limited manipulated variable parameter $c_{l}$ selection procedure

$c_{10}$ curve is the lower boundary of $u(0)$ and the area below the $c_{10}$ curve is highlighted; $c_{11}$ curve is the upper boundary of $u(1)$ and the area above the $c_{11}$ curve is highlighted. The same steps are applied to $c_{121}$ and $c_{122}$ curves that limit $u(2)$.

The non-highlighted area is the area from which it is possible to choose a value for $c_{1}$ and then, by using it, define a suitable sampling time $T_{0} . c_{1}$ value may be chosen from the middle of the non-highlighted area, but in this case, the manipulated variable $u$ will be limited by this inequality: $u_{\max }>|u(0)|>|u(1)|>|u(2)|$. If $c_{1}$ value is chosen from the leftmost point of the non-highlighted area (see Fig.2.), the manipulated variable will be limited by this inequality: $u_{\max }=|u(0)|=|u(1)|>|u(2)|$. After the value of $c_{1}$ is chosen it is possible to define a suitable sampling time $T_{0}$. Once this is done, the coefficients of the deadbeat controller are found using (5) and the design procedure is over.

\section{Simulation and experiments of the deadbeat control system}

Performance of the a forementioned controler design procedure can be found through the simulations and experiments.

A third order continuous object [2] was chosen and its structure is shown in Fig. 3.

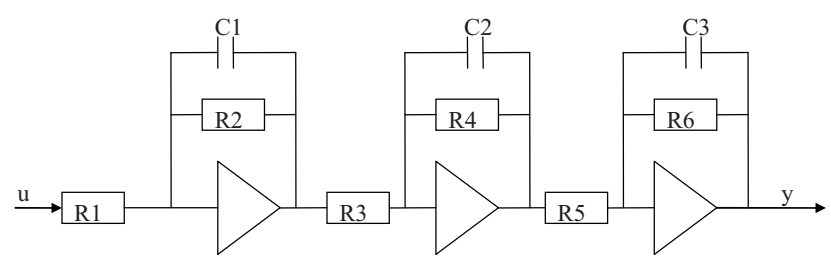

Fig. 3. Continuous object structure: $\mathrm{R} 1=1 \mathrm{M} \Omega ; \mathrm{R} 2=1 \mathrm{M} \Omega ; \mathrm{C} 1$ $=5 \mu \mathrm{F} ; \mathrm{R} 3=1 \mathrm{M} \Omega ; \mathrm{R} 4=1 \mathrm{M} \Omega ; \mathrm{C} 2=1 \mu \mathrm{F} ; \mathrm{R} 5=1 \mathrm{M} \Omega$; $\mathrm{R} 6=1 \mathrm{M} \Omega ; \mathrm{C} 3=5 \mu \mathrm{F}$

If we consider the parameters of a chosen object indicated in Fig. 3, we can write continuous transfer function

$$
W(s)=\frac{1}{(5 s+1) \cdot(s+1) \cdot(5 s+1)} .
$$

The object response $y$, simulated by Matlab software, to the unit step input $u$, is depicted in Fig. 4.

The continuous object is connected to the PLC Modicon 140 CPU 113 03, which has a realized deadbeat controller and measures the output $y$ signal of the object. A single pole low pass input filter processes the object's output signal $y$; the resolution of the $\mathrm{A} / \mathrm{D}$ converter of the analogue input module is $15 \mathrm{Bit}$; the signal voltage is measured with an absolute accuracy error at $25{ }^{\circ} \mathrm{C}$ that equals $\pm 0.03 \%$. $12 \mathrm{Bit} \mathrm{D} / \mathrm{A}$ converter of the analogue output module processes the output signal $u$ of the controller; the voltage output range of the analogue output module is $0-10 \mathrm{VDC}$, output accuracy error at $25{ }^{\circ} \mathrm{C}$ equals $\pm 0.15 \%$ of the full scale. 


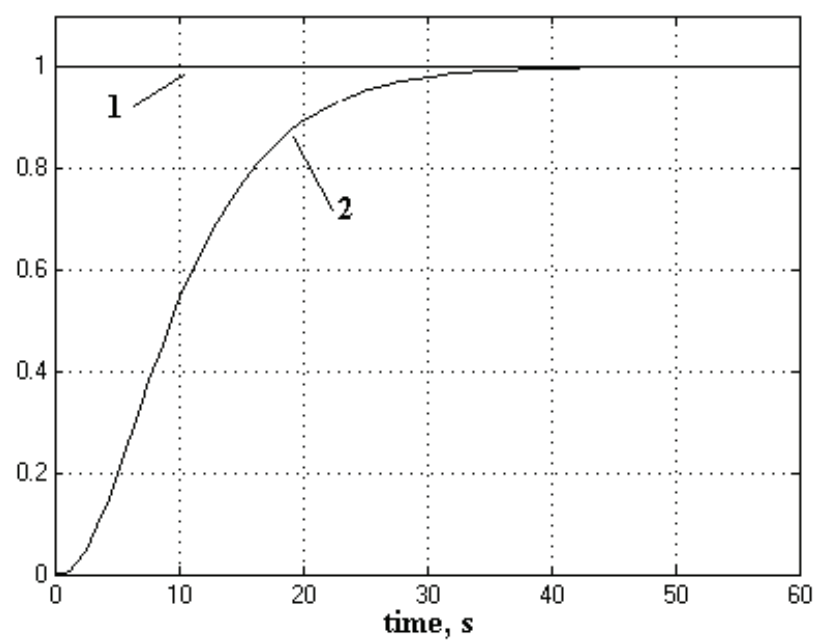

Fig. 4. Object response (2-y), simulated by Matlab software, to the unit step input $(1-u)$

Continuous object response $y$ to the unit step voltage input $u$, is shown in Fig. 5.

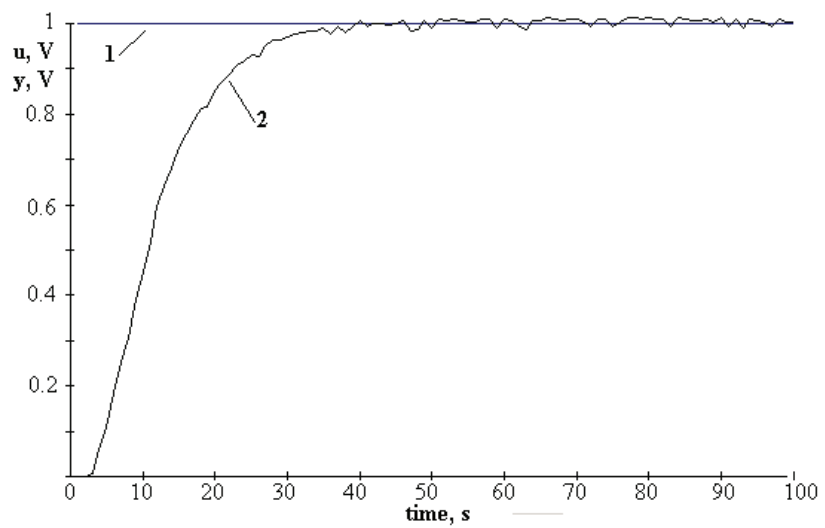

Fig. 5. Continuous object response (2-y) to unit step voltage input $(1-u)$

By comparing the real object response with the one simulated by Matlab, it can be seen that they are fairly similar. The real object response is with a disturbance. The transfer function given in the expression (16) will henceforth be used to design the deadbeat controller.

The design of the deadbeat controller is executed in Matlab [3]. The continuous object transfer function is converted to discrete time assuming a zero order hold on the inputs. By using equations (1) and (2), while holding that $u(0)=3.0$, we get the transfer function of the deadbeat controller

$$
\left\{\begin{array}{l}
\mathrm{W}_{\mathrm{DC}}(\mathrm{z})=\frac{3.0007-2.553 \mathrm{z}^{-1}+0.5591 z^{-2}-0.0068 z^{-3}}{1-0.4525 \mathrm{z}^{-1}-0.5238 z^{-2}-0.0237 z^{-3}}, \\
T_{0}=4.35 s .
\end{array}\right.
$$

By using a method, which includes Matlab simulation and experimenting with the PLC, we get the deadbeat control system (see Fig. 1.) responses $y$ to the unit step input reference signal $g$.

Fig. 6. shows that the system response has a finite setling time. The response ends in $8.91 \mathrm{~s}$ (the response remain within a $2 \%$ of its final value) after three steps of the control signal, because this is a third order object. The system response does not have any indications of overshooting. Fig. 7. shows that the disturbances affecting the real object, also influence the system response and the controller's output, which depends on the system response. The system response has a overshoot of $7 \%$, while the settling time takes 5 sampling time units.

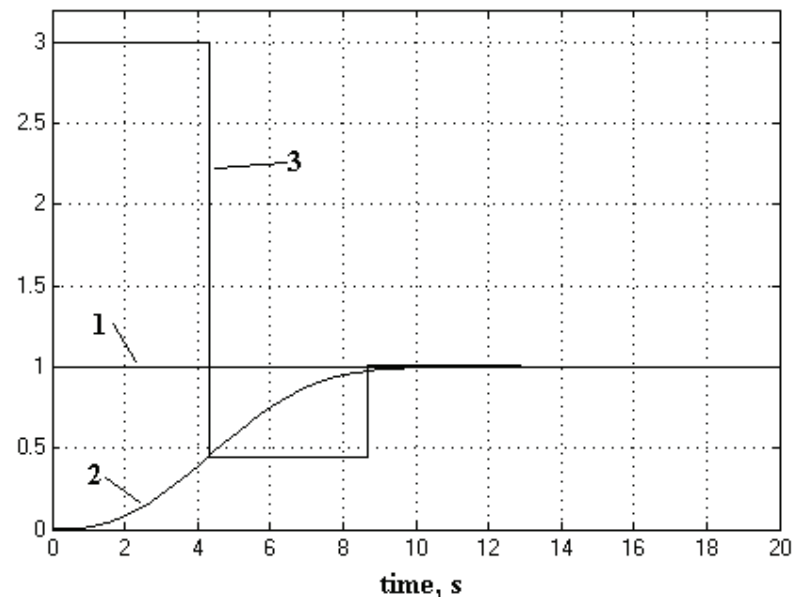

Fig. 6. Matlab simulated deadbeat system response (2-y) to unit step reference input signal (1-g), 3 - controller output $u$

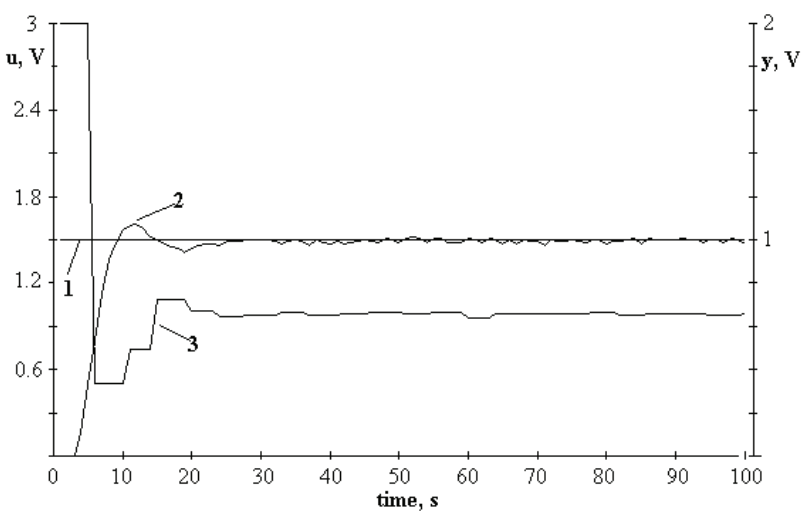

Fig. 7. PLC implemented deadbeat system response (2-y) to unit step reference input signal $(1-g), 3$ - controller output $u$

The next step will be design of the deadbeat controller with limited output using equations (1) and (5). By using the additional procedure shown in Fig. 2, for choosing coefficient $c_{1}$, we find the transfer function of the deadbeat controller, holding that $u(0)=3.0=u(1)$, because $c_{10}=c_{11}=1.2826$.

$$
\left\{\begin{array}{l}
\mathrm{W}_{\mathrm{DC}}(\mathrm{z})=\frac{3.0+0.0001 \mathrm{z}^{-1}-3.5635 z^{-2}+1.6735 z^{-3}-0.11 z^{-4}}{1-0.1466 \mathrm{z}^{-1}-0.4542 z^{-2}-0.3668 z^{-3}-0.0324 z^{-4}}, \\
T_{0}=2.539 s .
\end{array}\right.
$$

By using a method, which includes Matlab simulation, we get the deadbeat control system response $y$ to the unit step input reference signal $g$.

Fig. 8. shows shows that the system response has a finite setling time. The response ends in $8 \mathrm{~s}$ after four steps of the control signal. The system response does not have any indications of overshooting. The value of the control signal $u(2)$ is negative (then $g=1$ ) and thus cannot be realized with PLC analogue output module. 


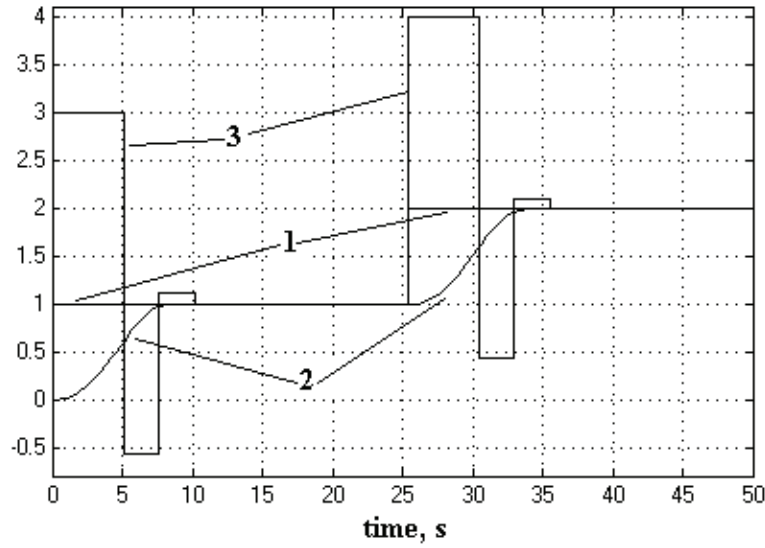

Fig. 8. Matlab simulated deadbeat system with limited controller output response $(2-y)$ to unit step reference input signal (1-g), $3-$ controller output $u$

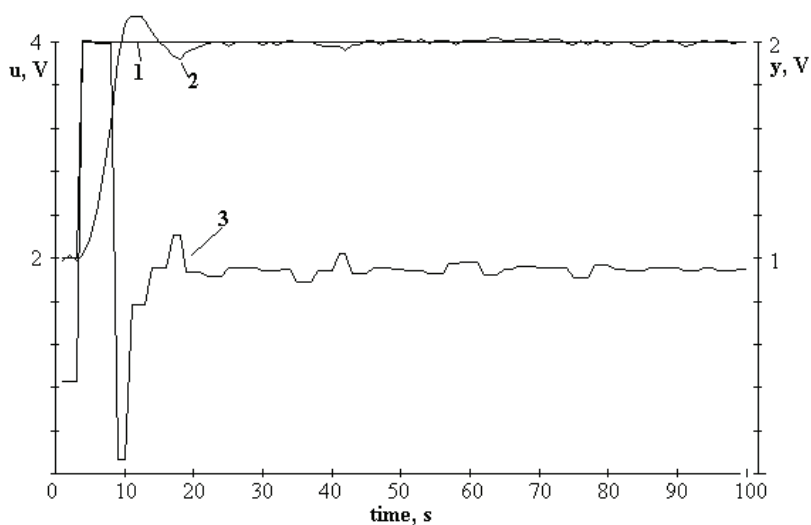

Fig. 9. PLC implemented deadbeat system with limited controller output response $(2-y)$ to step reference input signal $(1-g), 3-$ controller output $u$

So experiment with the PLC includes investigation of the deadbeat system response to step reference signal, when system output is $y=1$.
Fig. 9. shows that the system response has a overshoot of $7 \%$, while the transition takes more than 6 sampling time units.

It can be concluded that the responses of the experiments follows the system's response to the Matlab simulation with an error.

\section{Conclusions}

The presented procedure for choosing the deadbeat controller parameter $c_{l}$ allows for a decrease in the sampling time $T_{0}$, without increasing the maximum allowed value of the control signal.

The following observations were made based on such results. Simulation results show that even though the control increases by one-step, the length of the settling time of the system response can be lower than that of the deadbeat controller without any modifications.

It was found that the deadbeat controller is not of high quality when taking into account the changes in the parameters of an object. The quality of the deadbeat control system is influenced by the accuracy of the transfer function of the object. That is why it is crucial to have a reliable method for recognizing the transfer function of the object.

\section{References}

1. Isermann R. Digital control systems. - Springer-Verlag New York, 1996. - 350 p.

2. Balasevicius L., Rimkus K. System parameters identification in the state space // Proceedings of International Conference Electrical and Control Technologies'2009. Kaunas: Technologija, 2009. - P. 103-106.

3. Hetthéssy J., Barta A., Bars R. Dead beat controller design. - Ebook, 2004. - 5 p.

L. Balasevicius, G. Dervinis. Design of the Deadbeat Controller with Limited Output // Electronics and Electrical Engineering. Kaunas: Technologija, 2011. - No. 4(110). - P. 93-96.

There is presented a method for finding the parameters of the deadbeat controller in Matlab environment. The method is based on the introduction of an additional polynomial into the transfer function of the controller. The method for determining the additional polynomial coefficient of a deadbeat controller is based on creating the family of the coefficient curves and defining the permissible selection area. The method was tested by using simulations in Matlab environment and realizing the deadbeat control system for the third order object in the PLC. Simulation results in Matlab show that even though the control increases by one-step, the settling time of the system response can be lower than that of the deadbeat controller without any modifications. Based on the obtained results it can be concluded that the results confirm the idea of defining the parameters of the transfer function of a deadbeat controller with a limited output. Ill. 9, bibl. 3 (in English; abstracts in English and Lithuanian).

L. Balaševičius, G. Dervinis. Aperiodinio reguliatoriaus su apribotu išèjimu projektavimas // Elektronika ir elektrotechnika. Kaunas: Technologija, 2011. - Nr. 4(110). - P. 93-96.

Pateiktas aperiodinio reguliatorius parametrų nustatymo Matlab aplinkoje metodas, pagristas papildomo polinomo ivvedimu $\mathfrak{i}$ reguliatoriaus perdavimo funkcija. Aperiodinio reguliatoriaus papildomo polinomo koeficiento nustatymo metodas remiasi koeficiento kreivių šeimos sudarymu ir leistinos parinkti zonos apibrěžimu. Metodas išbandytas modeliuojant Matlab aplinkoje ir taikant aperiodinio valdymo sistemą trečios eilès objektui programuojamame loginiame valdiklyje. Modeliavimo Matlab rezultatai rodo, kad nors valdymas pailgèja vienu žingsniu, tačiau sistemos reakcijos pereinamojo proceso trukmè gali būti trumpesnè negu aperiodinio nemodifikuoto reguliatoriaus. Remiantis gautais rezultatais galima teigti, jog rezultatai patvirtino aperiodinio reguliatoriaus su apribotu išèjimu perdavimo funkcijos parametrų nustatymo idèją. Il. 9, bibl. 3 (anglų kalba; santraukos anglų ir lietuvių k.). 